\title{
Recombination at the coagulase locus in Staphylococcus aureus: plasmid integration and amplification
}

\author{
Damien McDevitt, Elisabeth R. Wann and Timothy J. Foster* \\ Microbiology Department, Moyne Institute, Trinity College, Dublin 2, Ireland
}

(Received 16 September 1992; revised 13 November 1992; accepted 17 December 1992)

\begin{abstract}
The integrating plasmid pCOA18, comprising pUC18 linked to a mutated coagulase (coa) gene from Staphylococcus aureus, and constructed by substituting coa sequences with a tetracycline (Tc)-resistance marker $\left(\Delta c o a:\right.$ : $\mathbf{T c}^{\mathrm{r}}$ ), was transformed into Staphylococcus aureus $\mathbf{R N 4 2 2 0}$, where it underwent recombination with the chromosomal coa locus. Allele-replacement mutants were recovered at a low frequency directly after transformation. The majority of transformants carried pCOA18 integrated in the chromosome by a single Campbell-type recombination event. The majority of integrants contained tandem repeats of pCOA18 and expressed high levels of resistance to Tc $\left(>30 \mu \mathrm{g} \mathrm{ml}^{-1}\right)$ compared to the single-copy integrants and allelereplacement mutants $\left(15 \mu \mathrm{g} \mathrm{ml}^{-1}\right)$. Transduction of a single-copy integrant to a $\mathrm{Coa}^{+}$recipient allowed the cointegrant to be resolved and allele-replacement recombinants to be selected. In addition, growth of a single-copy integrant on high concentrations of Tc $\left(>30 \mu \mathrm{g} \mathrm{ml}^{-1}\right)$ selected for amplified derivatives at a frequency of $10^{-5}$. It was estimated that up to 19 copies of pCOA18 could occur in a tandem array in the chromosome.
\end{abstract}

\section{Introduction}

The isolation of site-specific mutations in genes coding for putative virulence factors has provided new opportunities to analyse the virulence mechanisms of bacteria (Foster, 1992; Finlay, 1992). In Staphylococcus aureus, allele-replacement mutagenesis and transposon mutagenesis with Tn551 (Pattee, 1981) and Tn916 (Jones et al., 1987) are commonly used methods for isolating site-specific mutations (Foster \& McDevitt, 1992). These transposons insert into target DNA sequences essentially at random by illegitimate recombination whereas mutations in chromosomal genes can be specifically targeted by homologous recombination events such as directed plasmid insertion or allele-replacement with in-vitroconstructed mutant alleles.

Several procedures based on the instability of plasmid vectors have been employed to isolate allele-replacement mutants in $S$. aureus. A shuttle plasmid carrying the mutated allele was introduced into $S$. aureus along with a second incompatible plasmid (O'Reilly et al., 1986; Patel et al., 1987; Phonimdaeng et al., 1990). The incompatible plasmid was selected by growth in selective

*Author for correspondence. Tel. 3531 7022014; fax 3531 6799294.

Abbreviation: Tc, tetracycline. liquid media for 100-200 generations. In this way, the shuttle plasmid was eliminated from the majority of cells in the population and rare recombinants with replacement mutations in the chromosomal locus were detected.

Temperature-sensitive plasmids and integrating plasmid vectors have been used recently to deliver mutated alleles for allele-replacement (Sloane et al., 1991; McDevitt et al., 1992). Temperature-sensitive plasmids can be eliminated by growth at restrictive temperatures while integrating vectors lack a functional origin of replication and so will be lost during the growth that occurs after the plasmid is introduced by transformation. Integrating plasmids can be used for mutagenesis only if the frequency of plasmid transformation is high. Protoplast transformation in $S$. aureus is often not sufficiently reliable to use integrating plasmids. Recently, plasmid transformation frequencies of $10^{5}$ per $\mu \mathrm{g}$ of DNA have been achieved by electroporation (Oskouian \& Stewart, 1990). This has facilitated the use of integrating plasmids in S. aureus (McDevitt et al., 1992).

This paper reports experiments with an integrating vector carrying a deletion-substitution mutation in the coagulase gene $\left(\Delta c o a:: \mathrm{Tc}^{\mathrm{r}}\right)$ of $S$. aureus. The objective was to determine if insertions of the plasmid into the coa locus or allele-replacement mutants could be directly isolated following transformation by electroporation. The majority of plasmid integrants obtained after 
Table 1. Staphylococcus aureus strains

Tc, tetracycline; Coa, coagulase; amplified fragments.

\begin{tabular}{|c|c|c|c|c|}
\hline Strain & $\begin{array}{l}\text { Relevant } \\
\text { genotype }\end{array}$ & $\begin{array}{c}\text { Relevant } \\
\text { phenotype }\end{array}$ & Properties & $\begin{array}{l}\text { Source or } \\
\text { reference }\end{array}$ \\
\hline Newman & & $\mathrm{Coa}^{+}$ & High level of coagulase & $\begin{array}{l}\text { Duthie \& } \\
\text { Lorenz (1952) }\end{array}$ \\
\hline RN4220 & & $\mathrm{Coa}^{+}$ & $\begin{array}{l}\text { Mutant of } 8325-4 \text { capable } \\
\text { of stably maintaining shuttle } \\
\text { plasmids }\end{array}$ & $\begin{array}{l}\text { Kreiswirth } \\
\text { et al. }(1983)\end{array}$ \\
\hline DU5857 & coa::pCOA18 & $\mathrm{Coa}^{+} \mathrm{Tc}^{\mathrm{r}}$ & $\begin{array}{l}\text { Amplified pCOA } 18 \text { cointegrate } \\
\text { of } \mathrm{RN} 4220\end{array}$ & This study \\
\hline DU5861 & $\Delta c o a:: \mathrm{Tc}^{\mathrm{r}}$ & $\mathrm{Coa}^{-} \mathrm{Tc}^{\mathrm{r}}$ & $\begin{array}{l}\text { Allele-replacement mutant } \\
\text { of RN4220 }\end{array}$ & $\begin{array}{l}\text { McDevitt et al. } \\
\text { (1992) }\end{array}$ \\
\hline DU5862 & $\begin{array}{l}\text { coa::pCOA18 } \\
\text { coa }\end{array}$ & $\mathrm{Coa}^{-} \mathrm{Tc}^{\mathrm{r}}$ & $\begin{array}{l}\text { Amplified pCOA18 cointegrant } \\
\text { of RN4220 with deletion in coa }\end{array}$ & This study \\
\hline DU5863 & coa::pCOA18 & $\mathrm{Coa}^{+} \mathrm{Tc}^{\mathrm{r}}$ & $\begin{array}{l}\text { Single-copy pCOA18 } \\
\text { integrant of RN } 4220 \text { on } \\
\text { left-hand side of coa }\end{array}$ & This study \\
\hline DU5864 & $c o a:: \mathrm{pCOA} 18$ & $\mathrm{Coa}^{+} \mathrm{Tc}^{\mathrm{r}}$ & $\begin{array}{l}\text { Single-copy pCOA18 } \\
\text { integrant of RN4220 on } \\
\text { right-hand side of coa }\end{array}$ & $\begin{array}{l}\text { McDevitt et al. } \\
\text { (1992) }\end{array}$ \\
\hline DU5865 & $\begin{array}{l}c o a:: p C O A 18^{\sim} \\
c o a^{\sim}\end{array}$ & $\mathrm{Coa}^{+} \mathrm{Tc}^{\mathrm{r}}$ & $\begin{array}{l}\text { Amplified pCOA18 integrant } \\
\text { derived from DU5864. } \\
\text { Coagulase amplified }\end{array}$ & This study \\
\hline DU5881 & coa::pCOA18 & $\mathrm{Coa}^{+} \mathrm{Tc}^{\mathrm{r}}$ & $\begin{array}{l}\text { Amplified pCOA18 integrant } \\
\text { derived from DU5864 }\end{array}$ & This study \\
\hline DU5884 & coa::pCOA18 & $\mathrm{Coa}^{+} \mathrm{Tc}^{\mathrm{r}}$ & $\begin{array}{l}\text { Amplified pCOA18 integrant } \\
\text { derived from DU } 5881\end{array}$ & This study \\
\hline DU5885 & coa::pCOA18 & $\mathrm{Coa}^{+} \mathrm{Tc}^{\mathrm{r}}$ & $\begin{array}{l}\text { Amplified pCOA18 integrant } \\
\text { expressing highest level of } \\
\text { resistance to Tc. Derived from } \\
\text { DU5881 }\end{array}$ & This study \\
\hline
\end{tabular}

Table 2. Plasmids

$\mathrm{Cm}$, chloramphenicol; Tc, tetracycline; Ap, ampicillin.

\begin{tabular}{|c|c|c|c|c|}
\hline Plasmid & Host & Markers & Relevant properties & $\begin{array}{l}\text { Source or } \\
\text { Reference }\end{array}$ \\
\hline pCW59 & S. aureus & $\mathrm{Cm}^{\mathrm{r}} \mathrm{Tc}^{\mathrm{r}}$ & $\begin{array}{l}\text { Contains a gene for } \mathrm{Tc}^{\mathrm{r}} \\
\text { on a } 2.35 \mathrm{~kb} \\
\text { HindIII fragment }\end{array}$ & $\begin{array}{l}\text { Wilson et al. } \\
\text { (1981) }\end{array}$ \\
\hline pBluescript & E. coli & $\mathrm{Ap}^{\mathrm{r}}$ & Cloning vector & $\begin{array}{l}\text { Short et al. } \\
(1988)\end{array}$ \\
\hline pCOA14 & E. coli & $A p^{r}$ & $\begin{array}{l}5.4 \mathrm{~kb} \mathrm{KpnI} \mathrm{coa} \mathrm{fragment} \\
\text { in pUC19 }\end{array}$ & $\begin{array}{l}\text { Phonimdaeng } \\
\text { et al. (1988) }\end{array}$ \\
\hline pCOA18 & E. coli & $A p^{r} T c^{r}$ & $\begin{array}{l}\text { pBluescript with a } 5.4 \mathrm{~kb} K p n \mathrm{I} \\
\text { fragment carrying the } \\
\Delta \text { coa:: } \mathrm{Tc}^{\mathrm{r}} \text { mutation }\end{array}$ & $\begin{array}{l}\text { McDevitt et al. } \\
\text { (1992) }\end{array}$ \\
\hline
\end{tabular}

transformation unexpectedly carried tandem multimers of the plasmid in the coa locus. Campbell integrants could be resolved by transduction to yield replacement mutants.

\section{Methods}

Bacterial strains and plasmids. The bacterial strains and plasmids are listed in Tables 1 and 2 respectively.
Bacterial growth media, antibiotics and chemicals. Escherichia coli strains harbouring plasmids were routinely grown in L-broth and Lagar (Miller, 1972). Ampicillin $\left(100 \mu \mathrm{g} \mathrm{ml}^{-1}\right)$ was incorporated as appropriate. $S$. aureus strains were grown in Trypticase soy broth or agar incorporating the antibiotic tetracycline $(\mathrm{Tc})$ at concentrations from $2-100 \mu \mathrm{g} \mathrm{ml}^{-1}$ where appropriate. Laboratory chemicals used were of analytical grade obtained from Sigma or were the best grade available from $\mathrm{BDH}$.

Introduction of plasmid DNA into $S$. aureus by electrotransformation. Cells were grown for $16 \mathrm{~h}$ in TSB at $37^{\circ} \mathrm{C}$ and diluted in $100 \mathrm{ml}$ of fresh 
TSB at $37^{\circ} \mathrm{C}$ until the $\mathrm{OD}_{540}$ had reached $0 \cdot 2$. Cells were collected by centrifugation at $10000 \mathrm{~g}$ and washed twice with ice-cold $0.5 \mathrm{M}$ sucrose. The cells were then resuspended in $1 \mathrm{ml}$ of ice-cold $0.5 \mathrm{M}$ sucrose and incubated on ice for $15 \mathrm{~min}$. The cells were recentrifuged and resuspended in $1 \mathrm{ml}$ of ice-cold $5 \mathrm{M}$-sucrose. Cells $(100 \mu \mathrm{l})$ and DNA at a concentration of $1 \mu \mathrm{g} \mathrm{m}^{-1}$ were mixed in a sterile microfuge tube and incubated on ice for $1 \mathrm{~min}$. The mixture was transferred to a chilled cuvette of a Bio-Rad Gene Pulser and samples were electroporated at $2.5 \mathrm{kV}, 25 \mu \mathrm{F}$ capacitance with resistance varying from 200-600 $\Omega$. The cells were then removed from the cuvette, diluted in sterile TSB and plated on TSA containing the appropriate selective drug. This procedure was adapted from Oskouian \& Stewart (1990).

Manipulation of DNA. DNA-modifying enzymes were purchased from Boehringer or Promega and were used according to the manufacturers' instructions. DNA manipulations were performed using standard procedures (Sambrook et al., 1989; Ausubel et al., 1987). DNA hybridization was performed by the method of Southern (1975). $S$. aureus genomic DNA was purified by a modification of the method of Mekalanos (1983) as described by O'Reilly et al. (1986). Probe DNA was nick-translated (Rigby et al., 1977) by using $\left[\alpha-{ }^{32}\right.$ P]dATP (New England Nuclear).

Measurement of coagulase activity. Coagulase activity was determined by adding $0.5 \mathrm{ml}$ of $S$. aureus culture supernatants diluted $1: 2$ and $0.5 \mathrm{ml}$ of a 1:3 dilution in PBS of rabbit plasma. The expression of coagulase resulted in clot formation after $24 \mathrm{~h}$ incubation at $37^{\circ} \mathrm{C}$ (Anderson et al., 1982).

Transduction. Transduction in $S$. aureus was performed by the method of Asheshov (1966) by using bacteriophage 85.

Amplification of the single-copy integrant strain DU5864. In order to isolate amplified derivatives of strain DU5864, cultures were grown in $1 \mu \mathrm{g} \mathrm{Tc} \mathrm{ml}^{-1}$ to induce the Tc resistance determinant and dilutions were plated on TSA incorporating $\mathrm{Tc}$ at concentrations from $50-200 \mu \mathrm{g} \mathrm{ml}^{-1}$. Colonies were isolated from the plate containing $50 \mu \mathrm{g}$ $\mathrm{Tc} \mathrm{ml} l^{-1}$ and they were maintained on plates containing $30 \mu \mathrm{g} \mathrm{Tc} \mathrm{ml} l^{-1}$. The amplified strain DU5881 was plated on Tc concentrations ranging from $100-400 \mu \mathrm{g} \mathrm{ml}^{-1}$. Colonies grew on concentrations of Tc up to $120 \mu \mathrm{g} \mathrm{ml}^{-1}$. Several of these were picked and maintained on agar containing $50 \mu \mathrm{g} \mathrm{Tc} \mathrm{ml} l^{-1}$.

Estimation of copy number using densitometry. The relative intensities of the bands on autoradiograms were determined by scanning each lane with a CD-50 chromatogram-densitometer (Shimadzu). The densitometer was set to measure reflectance at $600 \mathrm{~nm}$ and the scanning beam slit was set at $3 \times 5 \mathrm{~mm}$ (a width sufficient to cover an entire band). The different heights of the three peaks observed for the singlecopy integrant reflected the homology that each fragment had with the pCOA14 probe. When calculating the copy number, this was taken into account by dividing the peak height of the $5.4 \mathrm{~kb} \mathrm{KpnI} \mathrm{fragment} \mathrm{by} \mathrm{that}$ of the $2.5 \mathrm{~kb} \mathrm{KpnI}$ fragment for the single-copy integrant. A ratio of 1.9 was obtained. It was assumed that this ratio was maintained in all samples. In the amplified strains, the peak height of the amplified $2.5 \mathrm{~kb}$ KpnI fragment was multiplied by 1.9 and then divided by the corresponding peak height of the single-copy $5.4 \mathrm{~kb} \mathrm{KpnI}$ fragment.

Measurement of tetracycline resistance. The efficiency of plating (e.o.p.) on Tc medium was determined with cultures that had been grown in $1 \mu \mathrm{g} \mathrm{Tc} \mathrm{ml}{ }^{-1}$. Dilutions of the broth culture were spread on plates containing $30 \mu \mathrm{g} \mathrm{Tc} \mathrm{ml}^{-1}$. The e.o.p. was defined as the ratio of colonies growing at $30 \mu \mathrm{g} \mathrm{ml}^{-1}$ compared to drug-free agar.

For $\mathrm{IC}_{50}$ determinations, cultures were grown overnight in $1 \mu \mathrm{g}$ $\mathrm{Tc} \mathrm{ml}^{-1}$ to induce expression of resistance and were then diluted to $10^{3}$ cells $\mathrm{ml}^{-1}$ and $100 \mu \mathrm{l}$ of each strain was plated onto agar containing Tc in the range $5-200 \mu \mathrm{g} \mathrm{ml}^{-1}$. The plates were incubated at $37^{\circ} \mathrm{C}$ for $18 \mathrm{~h}$.
The arbitrary end-point was defined as the concentration of drug at which there was reduction in colony size of about $50 \%$.

\section{Results}

Transformation with the integrating plasmid pCOA18

Plasmid pCOA18 comprises the $2.95 \mathrm{~kb} E$. coli vector plasmid pBluescript carrying the coa locus of $S$. aureus $8325-4$ with a deletion-substitution mutation - a $2.35 \mathrm{~kb}$ insert carrying a $T c$ gene from the $S$. aureus plasmid pCW59 replaces the coa gene (McDevitt et al., 1992). The mutated coa locus is flanked on both sides by about $1.6 \mathrm{~kb}$ of chromosomal DNA. It lacks a basic replicon that is functional in $S$. aureus. The initial objective of this work was to determine if pCOA 18 could be transformed into $S$. aureus by electroporation and to study the structure of the recombinants. It was anticipated that the majority of the $\mathrm{Tc}^{\mathrm{r}}$ transformants would contain the plasmid integrated in the coa locus by a single cross-over (Campbell-type integration) and that double recombination causing allele-replacement with $\Delta c o a:: \mathrm{Tc}^{\mathrm{r}}$ might be detected at a lower frequency.

Plasmid pCOA18 DNA was transformed into $S$. aureus strain RN4220 by electroporation selecting for Tc resistance. The frequency of transformation was $1 \times 10^{3}$ per $\mu$ g DNA. A control experiment with pCW59 DNA gave $2 \times 10^{5}$ transformants per $\mu \mathrm{g}$ DNA. Fifty $\mathrm{Tc}^{r}$ transformants were purified and tested for their level of resistance to $\mathrm{Tc}$ and for their expression of coagulase. Representatives were analysed by transduction and by Southern hybridization.

\section{Phenotype analysis of pCOA18 transformants}

Fifty $\mathrm{Tc}^{\mathrm{r}}$ transformants of strain RN4220 were tested for the expression of coagulase by the tube test and only two were negative (Table 3). One of these (strain DU5861) expressed resistance to $15 \mu \mathrm{g} \mathrm{Tc} \mathrm{ml} l^{-1}$ while the other (strain DU5862) expressed a higher level of resistance $\left(50 \mu \mathrm{g} \mathrm{ml}^{-1}\right)$. The remaining 48 transformants were $\mathrm{Coa}^{+}$. The majority of these $(42 / 48)$ expressed resistance to $50 \mu \mathrm{g} \mathrm{Tc} \mathrm{ml}^{-1}$ while the remaining six had lower level resistance. However, when the low-level resistant strains were plated on $30 \mu \mathrm{g} \mathrm{Tc} \mathrm{ml} l^{-1}$, colonies grew at a frequency of $1 \times 10^{-5}$. In contrast, $\mathrm{Tc}^{\mathrm{r}}$ transformants which expressed high-level resistance such as DU5862 grew with $100 \%$ efficiency at $30 \mu \mathrm{g} \mathrm{Tc} \mathrm{ml}{ }^{-1}$.

\section{Transduction analysis}

Bacteriophage 85 was propagated on representatives of each of the phenotypic groups described above. The ability of the phage to transduce $\mathrm{Tc}$ resistance to the coagulase-proficient strain Newman was evaluated. 
Table 3. Properties of pCOA18 transformants

\begin{tabular}{|c|c|c|c|c|c|c|}
\hline Strain & $\begin{array}{l}\text { Resistance to } \mathrm{Tc} \\
\left(\mathrm{IC}_{50}, \mu \mathrm{g} \mathrm{ml}^{-1}\right)\end{array}$ & $\begin{array}{c}\text { e.o.p. on } 30 \mu \mathrm{g} \\
\mathrm{Tc} \mathrm{\textrm {ml } ^ { - 1 }}\end{array}$ & $\begin{array}{c}\text { Coagulase } \\
\text { production }\end{array}$ & $\begin{array}{c}\text { Transduction } \\
\text { frequency }\end{array}$ & $\begin{array}{l}\text { No. of } \mathrm{Coa}^{-} \\
\text {transductants }\end{array}$ & $\begin{array}{c}\begin{array}{c}\text { Parental } \\
\text { strain }\end{array} \\
\end{array}$ \\
\hline \multicolumn{7}{|c|}{ Transformants } \\
\hline DU5861 & 15 & $<1 \times 10^{-7}$ & - & $1 \times 10^{-8}$ & $5 / 5$ & RN4220 \\
\hline DU5862 & 50 & $1 \cdot 0$ & - & $1 \times 10^{-6}$ & $0 / 8$ & RN4220 \\
\hline DU5863* & 15 & $2 \times 10^{-5}$ & + & $1 \times 10^{-8}$ & ND & RN4220 \\
\hline DU5864* & 15 & $2 \times 10^{-5}$ & + & $1 \times 10^{-8}$ & $6 / 31$ & RN4220 \\
\hline DU5857† & 50 & 1.0 & + & $1 \times 10^{-6}$ & $0 / 50$ & RN4220 \\
\hline \multicolumn{7}{|c|}{ Amplified derivatives } \\
\hline DU5865 & 50 & 1.0 & + & $1 \times 10^{-6}$ & $2 / 28$ & DU5864 \\
\hline DU5881 & 50 & ND & + & ND & ND & DU5864 \\
\hline DU5884 & 80 & ND & + & ND & ND & DU5881 \\
\hline DU5885 & 125 & ND & + & ND & ND & DU5881 \\
\hline
\end{tabular}

ND, Not done

* Representative of the $6 / 50 \mathrm{Coa}^{+}$transformants expressing low-level $\mathrm{Tc}^{\mathrm{r}}$.

+ Representative of the $42 / 50 \mathrm{Coa}^{+}$transformants expressing high-level $\mathrm{Tc}^{\mathrm{r}}$.

When $\mathrm{Tc}^{\mathrm{r}}$ transductants were selected with phage propagated on a low-level $\mathrm{Tc}^{\mathrm{r}} \mathrm{Coa}^{-}$transformant (strain DU5861), all of the five derivatives tested were $\mathrm{Coa}^{-}$and expressed the same low-level $\mathrm{Tc}$ resistance as the parental strain. This suggested that strain DU5861 carries the $\Delta c o a:: \mathrm{Tc}^{\mathrm{r}}$ mutation rather than an integrated plasmid. In contrast, with phage propagated on the $\mathrm{Coa}^{-}$ strain DU5862 none of the $8 \mathrm{Tc}^{\mathrm{r}}$ transductants which were tested were $\mathrm{Coa}^{-}$. This demonstrated that the $\mathrm{Coa}^{-}$ mutation of this strain was not caused by the $\mathrm{Tc}^{\mathrm{r}}$ marker.

The low-level $\mathrm{Tc}^{r} \mathrm{Coa}^{+}$transformants (DU5863 and DU5864) were probably derived from an integration of the pCOA18 plasmid in the coa locus of the chromosome by a Campbell-type recombination event. It has been reported that transduction of an integrated plasmid carrying an insertion mutation in a chromosomal gene and selection for the marker associated with the mutated gene can promote plasmid loss and the generation of an allele-replacement mutation (Sloane et al., 1991). Indeed, six of $31 \mathrm{Tc}^{\mathrm{r}}$ transductants of strain Newman that were selected from lysates of bacteriophage 85 propagated on strain DU5864 were $\mathrm{Coa}^{-}$. Each of these expressed lowlevel $\mathrm{Tc}^{\mathrm{r}}$ and when plated on $30 \mu \mathrm{g} \mathrm{Tc} \mathrm{ml}^{-1}$ no colonies grew.

Transducing phage was propagated on two strains that expressed high-level Tcr. One (strain DU5865) was selected from the low-level $\mathrm{Tc}^{\mathrm{r}}$ putative Campbell insertion strain DU5864, while strain DU5857 was isolated directly after transformation. The frequency of transduction of $\mathrm{Tc}^{\mathrm{r}}$ into strain Newman was about 100 fold higher than for phage propagated on strains such as DU5861 (allele replacement) or DU5863 and DU5864 (single-copy integrants), which express low level $\mathrm{Tc}^{\mathrm{r}}$. In one case (donor strain DU5857), no $\mathrm{Coa}^{-}$transductants were found among the 50 tested and 19/31 continued to express high-level resistance $\left(>30 \mu \mathrm{g} \mathrm{ml}^{-1}\right)$. However, with donor strain DU5865, 2/28 were $\mathrm{Coa}^{-}$and expressed low-level $\mathrm{Tc}^{\mathrm{r}}\left(15 \mu \mathrm{g} \mathrm{ml}^{-1}\right)$ while the rest were $\mathrm{Coa}^{+}$and expressed a higher level of $\mathrm{Tc}^{\mathrm{r}}$.

Transformants were streaked on agar containing Tc and many showed a mixture of small and large colonies. The small colonies either gave a mixture of small and large colonies again upon restreaking or they could not be propagated. Large colonies formed a homogeneously sized population when restreaked. More than half the transformants selected and restreaked on $2 \mu \mathrm{g} \mathrm{Tc} \mathrm{ml} l^{-1}$ could grow on Tc concentrations above $30 \mu \mathrm{g} \mathrm{ml}^{-1}$.

\section{Southern hybridization analysis}

Southern hybridization experiments were performed to investigate the structure of the coa loci in the transformants described above. Plasmids pCOA14 (which carries the wild-type strain 8325-4 coa gene on a $5.4 \mathrm{~kb}$ $K p n I$ fragment in pUC19) and pCW59 (which contains the $2.35 \mathrm{~kb}$ HindIII $\mathrm{Tc}^{\mathrm{r}}$ fragment used to inactivate the coa gene in pCOA18) were nick-translated and used as probes.

Fig. 1 shows the results of hybridizing genomic DNA of the putative allele-replacement mutant of RN4220 strain DU5861. It also examines the properties of strain DU5857, a Coa ${ }^{+}$transformant of RN4220 expressing high-level $\mathrm{Tc}^{\mathrm{r}}$. The parental $\mathrm{Coa}^{+}$strain RN4220 had a $5.4 \mathrm{~kb} K p n I$ fragment which hybridized to the coa probe pCOA14 (Fig. 1, lane A). The $5.4 \mathrm{~kb}$ fragment was missing in strain DU5861 and was replaced by fragments of $3.05 \mathrm{~kb}$ and $2.5 \mathrm{~kb}$ (Fig. 1, lane C). Fragments of the same size hybridized when strain DU5861 DNA was probed with pCW59 (carrying the $\mathrm{Tc}^{\mathrm{r}}$ marker) (Fig. 1, lanes $F$ ). The appearance of two hybridizing fragments in $K p n I$ digests is due to the $K p n I$ site present in the $\mathrm{Tc}^{\mathrm{r}}$ fragment of $\Delta c o a:: \mathrm{Tc}^{\mathrm{r}}$. DNA from the parental RN4220 strain did not hybridize with the pCW59 probe (Fig. 1, lane D). In contrast, strain DU5857 had four fragments 


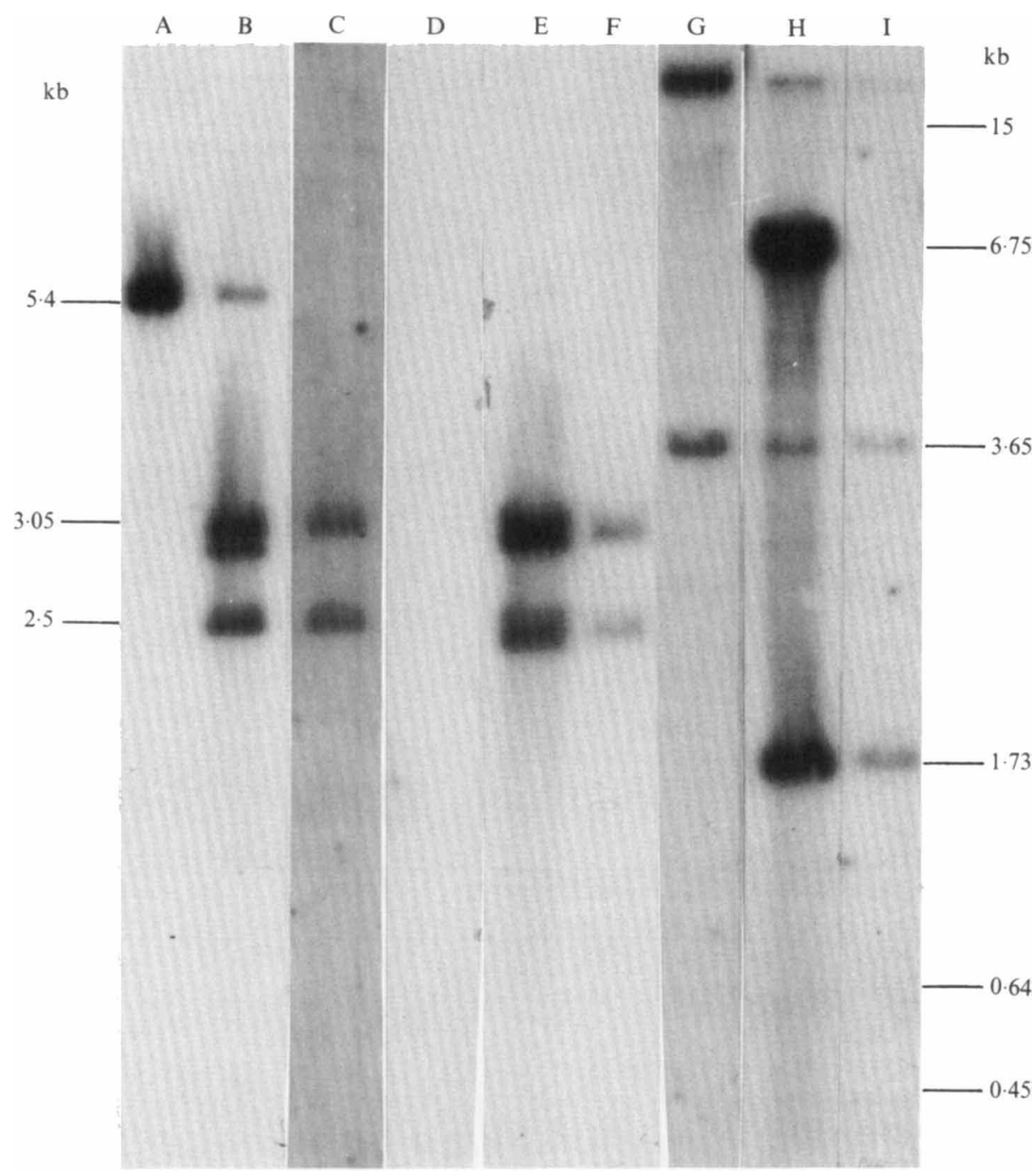

Fig. 1. Southern hybridization analysis of strains RN4220, DU5857 (RN4220 amplified integrant) and DU5861 (RN4220 $\Delta$ coa::Tcr). Chromosomal DNA from strain RN4220 wild-type was cleaved with $K p n I$ (lanes A and D) and with EcoRV (lane G). DNA from strain DU5857 was cleaved with KpnI (lanes B and E) and with EcoRV (lane H). Chromosomal DNA of strain DU5861 was cleaved with $K p n I$ (lanes $\mathrm{C}$ and F) and with $E c o \mathrm{RV}$ (lane I). Samples in lanes A-C and lanes G-I were probed with labelled pCOA14 while samples in lanes D-F were probed with labelled pCW59. The DNA loadings in each lane were similar (about $10 \mu \mathrm{g}$ )

which hybridized to the coa probe (Fig. 1, lane B), two of which also hybridized to the $\mathrm{Tc}^{\mathrm{r}}$ probe (Fig 1, lane E). The fragments of $3.05 \mathrm{~kb}, 2.95 \mathrm{~kb}$ and $2.5 \mathrm{~kb}$ were more intense than fragments in strain DU5861, suggesting that they were present in multiple copies in strain DU5857.

The structures were investigated further by cleaving with $E c o \mathrm{RV}$, an enzyme which cuts both within the $\mathrm{Tc}^{\mathrm{r}}$ insert and within sequences flanking the coa gene and the $\Delta c o a:: \mathrm{Tc}^{\mathrm{r}}$ substitution in pCOA18 (Fig. 2). Fragments of $>15 \mathrm{~kb}$ and $3.65 \mathrm{~kb}$ hybridized when DNA of the parental strain RN4220 was probed with pCOA14 DNA (Fig. 1, lane G). Similar sized fragments were also visible in the strain DU5857 sample (Fig. 1, lane H). However, additional fragments of $6.75 \mathrm{~kb}$ and $1.73 \mathrm{~kb}$ were observed and these were more intensely labelled. The simplest explanation for these findings is that plasmid pCOA18 became integrated into the coa locus by crossing-over on the left of the coa gene, and the plasmid was subsequently amplified by tandem duplication (Figs 2 and 3), a process that probably occurs by unequal crossing-over during chromosome replication (Anderson \& Roth, 1977). However, it is also possible that multimers of pCOA18 were transformed and became integrated in the chromosome. The amplified KpnI and EcoRV fragments are from within pCOA18 while the single copy $5.4 \mathrm{~kb} K p n I$ fragment and the $3.65 \mathrm{~kb}$ and $>15 \mathrm{~kb}$ EcoRV fragments were exclusively composed of coa DNA flanking the amplified region (Fig. 2). The 

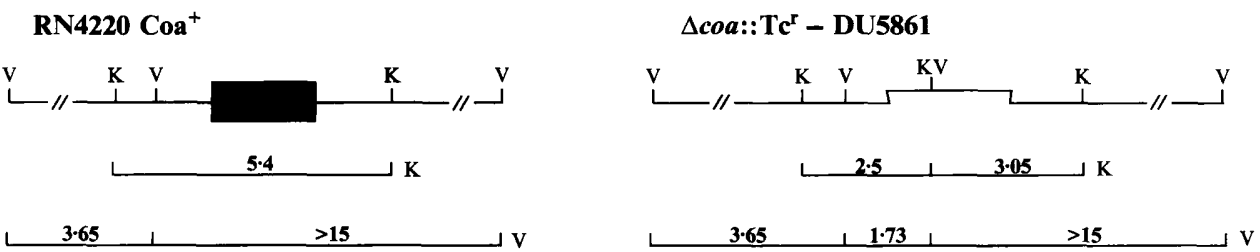

\section{Single-copy integrant A - DU5864}

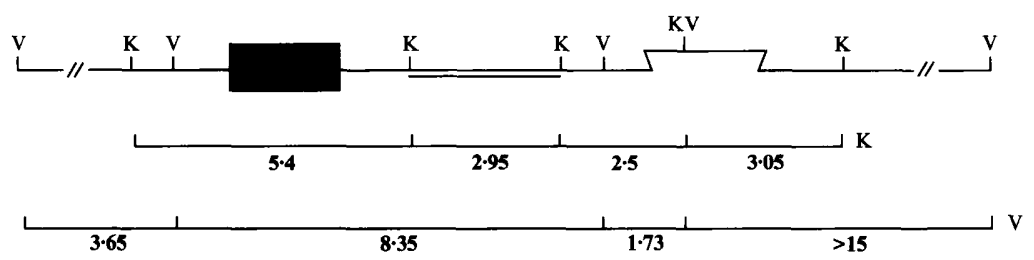

Single-copy integrant B - DU5863
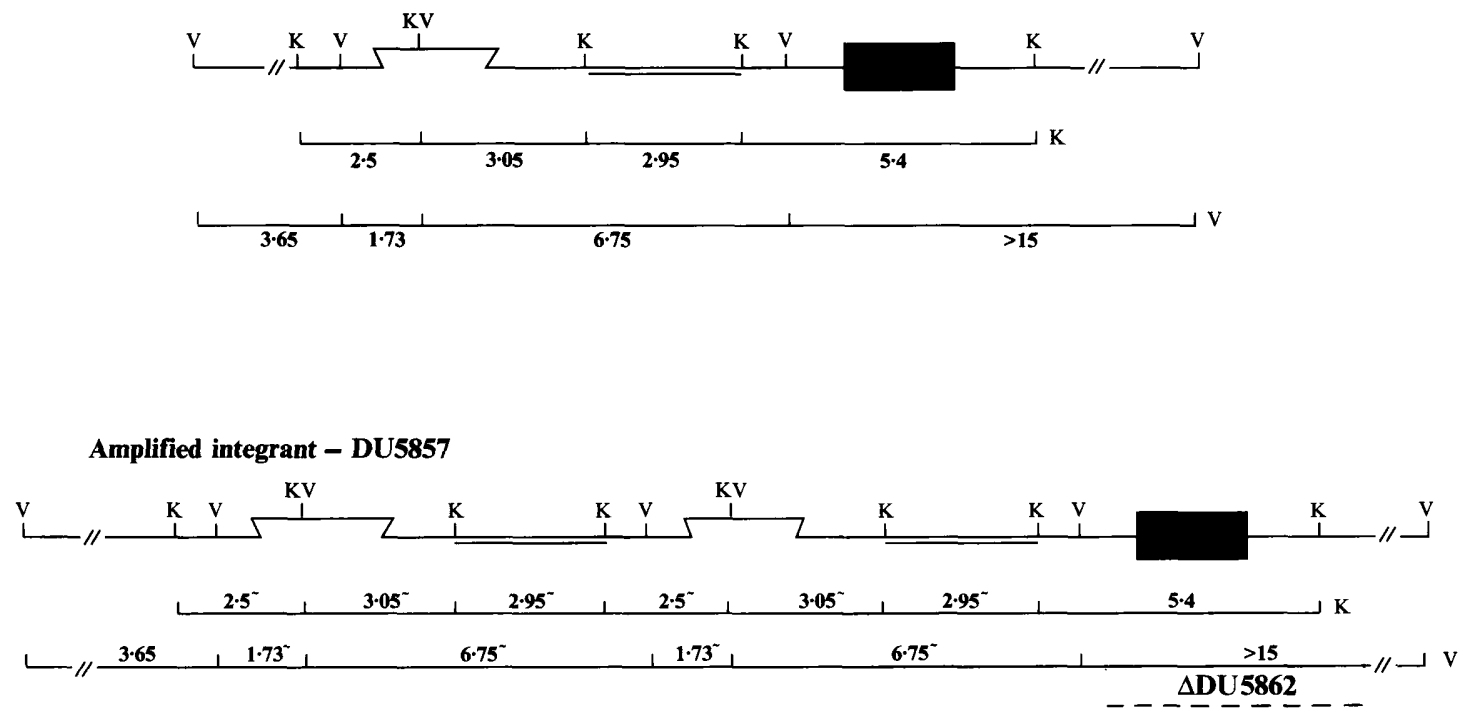

Fig. 2. Structure of the coa region in strains RN4220 $\mathrm{Coa}^{+}$, DU5861 (RN4220 $\Delta c o a:$ :Tcr), the single-copy integrant strains DU5864 (A) and DU5863 (B) and the amplified integrant strains DU5857 and DU5862. The closed box represents the coagulase gene while the elevated line represents the inserted $\mathrm{Tc}^{\mathrm{r}}$ fragment that replaces the coa gene in $\Delta c o a:: \mathrm{Tc}^{\mathrm{r}}$. The double line represents vector plasmid sequences while the single line represents flanking coa sequences. The deletion present in strain DU5862 is indicated. In the single-copy integrant strain DU5864 (A), pCOA18 has integrated on the right-hand side of the coa gene while in strain DU5863 (B), pCOA18 has integrated on the left-hand side. Restriction endonuclease cleavage sites are abbreviated as follow: V, EcoRV; K, KpnI; amplified fragments are marked .

allele-replacement mutant strain DU5861 (RN4220 $\Delta c o a:: \mathrm{Tc}^{\mathrm{r}}$ ) had three EcoRV fragments that hybridized to the pCOA14 probe, one of $3.65 \mathrm{~kb}$, one of $1.73 \mathrm{~kb}$ and one of $>15 \mathrm{~kb}$ (Fig. 1, lane I). The $3.65 \mathrm{~kb}$ fragment was from sequence located $5^{\prime}$ to the coa gene and was also present in the wild-type strain and in strain DU5857 (Fig. 2). The $1.73 \mathrm{~kb}$ fragment is composed of both coa and $\mathrm{Tc}^{\mathrm{r}}$ sequences (there is an $E c o \mathrm{RV}$ site located within the $\mathrm{Tc}^{\mathrm{r}}$ insert; Fig. 2). The large fragment was also a hybrid formed between the $\mathrm{Tc}^{\mathrm{r}}$ insert and $3^{\prime}$ coa sequences (Fig. 2) but was too large for any differences in size from the wild-type $>15 \mathrm{~kb}$ fragment to be detected under the conditions used.

Two $\mathrm{Coa}^{+}$transformants, strains DU5863 and DU5864, expressing low-level but amplifiable $\mathrm{Tc}^{\mathrm{r}}$ (putative single-copy Campbell integrants) were analysed by 


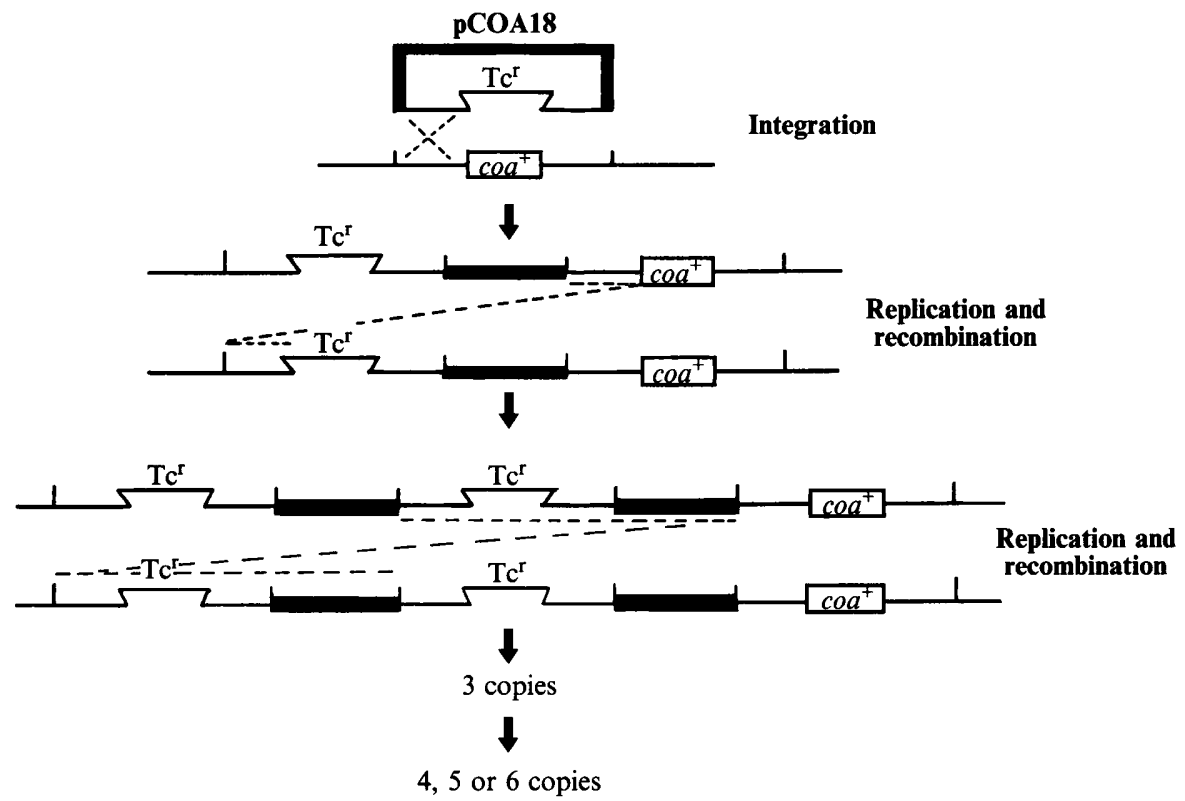

Fig. 3. Integration of pCOA18 into the chromosome and amplification by unequal crossing-over. The top part of the diagram shows a single recombination event between homologous sequences located to the left of the chromosomal coa gene (open box) and the mutated coa gene $\left(\Delta c o a:: \mathrm{Tc}^{\mathrm{r}}\right.$; elevated line) on pCOA18 that results in integration of the plasmid into the chromosome. The thick lines represent plasmid vector sequences and are not drawn to scale. The middle part of the diagram indicates one possible unequal crossing over event between homologous sequences flanking the $c o a^{+}$and $\Delta c o a:: \mathrm{Tc}^{\mathrm{r}}$ alleles that could occur after chromosome replication. The result is one chromosome carrying two copies of $\Delta c o a:: \mathrm{Tc}^{\mathrm{r}}$ and the plasmid vector (lower part of diagram). A second unequal crossingover event can occur between duplicated copies of the integrated pCOA18 during subsequent chromosome replication to give three copies of pCOA18 in a tandem array. Further amplification can occur during subsequent rounds of replication.

cutting genomic DNA with KpnI and EcoRV and probing with labelled coa pCOA14 DNA. Both strains had the same $K p n I$ fragment pattern (Fig. 4, lanes $\mathrm{C}$ and $\mathrm{E})$, which was identical to that of the amplified strain DU5857 (Fig. 1, lane B) except that the relative intensity of bands was different. Three of the four hybridizing $E c o$ RV fragments were also the same size in strains DU5863 and DU5864. However, a $8.35 \mathrm{~kb}$ EcoRV fragment was present in strain DU5864 (Fig. 4, lane H) while a $6.75 \mathrm{~kb} E c o \mathrm{RV}$ fragment was present in strain DU5863 (Fig. 4, lane J). This can be explained if pCOA18 became integrated by a single Campbell-type recombination event which took place on the left of the coa gene (strain DU5863) or on the right of the coa gene (strain DU5864) (Fig. 2). The different intensities of fragments can be explained by their composition; the $>15 \mathrm{~kb}$ fragment of strain DU5864 and the $6.75 \mathrm{~kb}$ fragment of strain DU5863 have less homology with the probe DNA sequences than the $>15 \mathrm{~kb}$ fragment of strain DU5863 and the $8.35 \mathrm{~kb}$ fragment of strain DU5864 (Fig. 2).

The high-level $\mathrm{Tc}^{r} \mathrm{Coa}^{-}$strain DU5862 appears to carry amplified copies of plasmid pCOA18. KpnI fragments of $3.05 \mathrm{~kb}, 2.95 \mathrm{~kb}$ and $2.5 \mathrm{~kb}$ hybridized strongly with the coa probe (Fig. 4, lane B). However, the
$5.4 \mathrm{~kb}$ KpnI coa fragment present in strain DU5857 (Fig. 2) was missing in strain DU5862 (Fig. 4, lane B). This suggests that the amplified plasmid is present in the coa locus but that a deletion of the wild-type coa gene had also occurred. Hybridization of EcoRV-cleaved strain DU5862 DNA showed fragments of $1.73 \mathrm{~kb}, 3.65 \mathrm{~kb}$ and $6.75 \mathrm{~kb}$ (Fig. 4, lane G) that were also present in strain DU5857 (Fig. 1, lane $\mathrm{H}$; the 1.73 and 6.75 fragments are amplified). The $8.6 \mathrm{~kb}$ fragment is probably a truncated derivative of the $>15 \mathrm{~kb}$ coa fragment seen in strain DU5863 caused by the deletion which affected the coa structural gene. Thus, strain DU5862 seems to carry a tandemly amplified copy of pCOA 18 derived from a Campbell cross-over to the left of the coa gene in the same way as strain DU5857. However, a large deletion has removed the single wild-type copy of the coa gene located to the right of the amplified structure (Fig. 2).

\section{Southern blotting analysis of amplified derivatives derived from the single-copy integrant strain DU5864}

Amplified derivatives of the single-copy integrant strain DU5864 were selected by plating on $30 \mu \mathrm{g} \mathrm{Tc} \mathrm{ml} l^{-1}$. One derivative, strain DU5865, was obtained in a single selection step but analysis of the fragment pattern of 


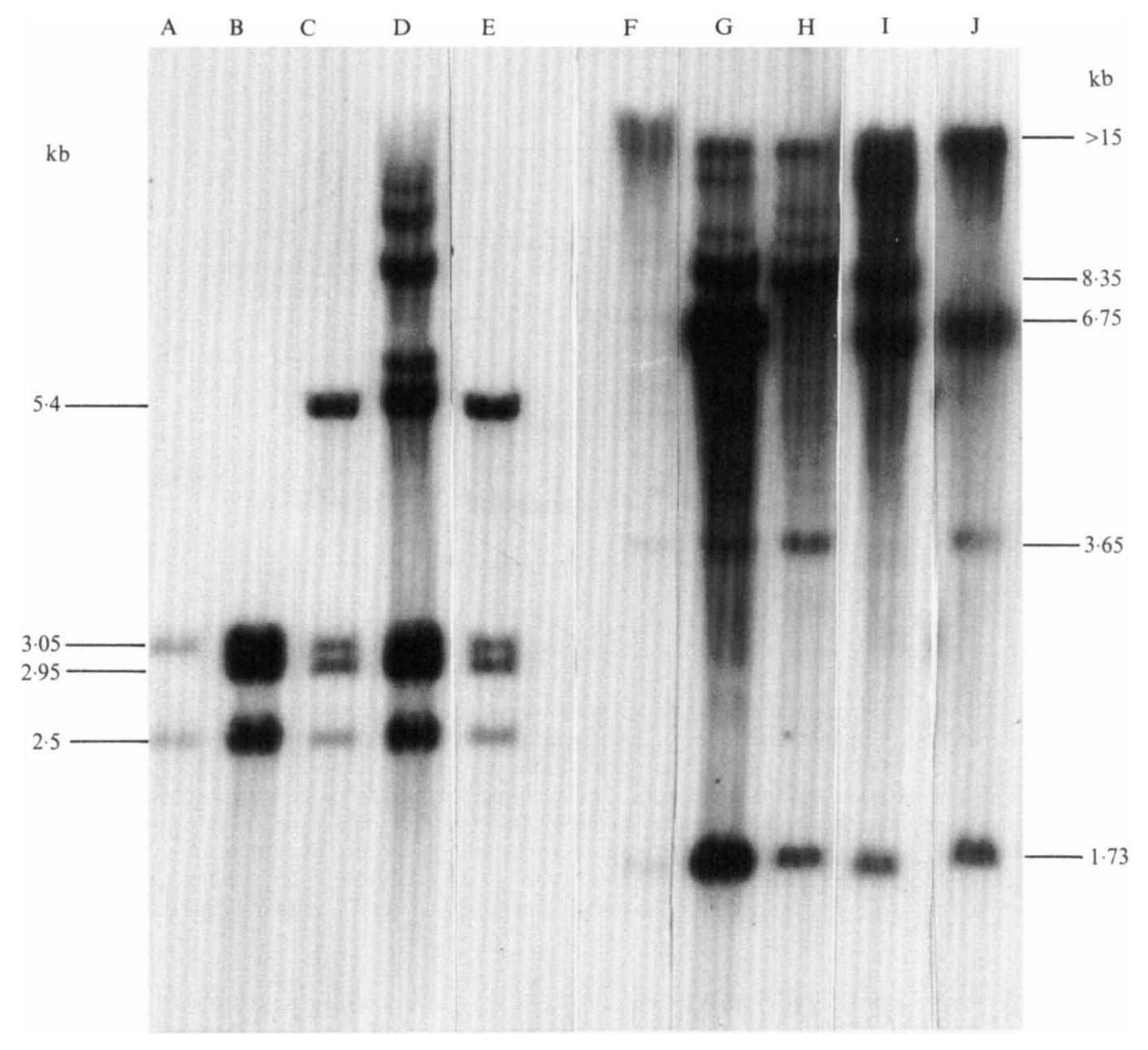

Fig. 4. Southern hybridization analysis of pCOA18 transformants. KpnI digestion was performed on chromosomal DNA from strains DU5861 (lane A), DU5862 (lane B), DU5864 (lane C), DU5865 (lane D) and DU5863 (lane E). The fragments above $5.4 \mathrm{~kb}$ in lane $\mathrm{D}$ and between $8.35 \mathrm{~kb}$ and $15 \mathrm{~kb}$ in lanes $\mathrm{G}, \mathrm{H}$ and I probably represent partial cleavage products. EcoRV digestion was performed on strains DU5861 (lane F), DU5862 (lane G), DU5864 (lane H), DU5865 (lane I) and DU5863 (lane J). Samples from lanes A-J were probed with labelled pCOA14. The DNA loading in each lane was similar (about $10 \mu \mathrm{g}$ ).

DNA from this strain suggests that the amplified structure is more complex than that of strains DU5857 or DU5862. Cleavage with KpnI revealed fragments of $2.5 \mathrm{~kb}, 2.95 \mathrm{~kb}, 3.05 \mathrm{~kb}$ and $5.4 \mathrm{~kb}$, all of which appeared to be amplified (Fig. 4, lane D). Comparing the intensity of the $5.4 \mathrm{~kb}$ fragment in strain DU5857 (Fig. 1, lane B) with that of strain DU5865 (Fig. 4, lane D) suggests that the wild-type coa gene had been amplified as well as pCOA18 (Fig. 5). The fragments above $5.4 \mathrm{~kb}$ in Fig. 4, lane $\mathrm{D}$ probably represent partial cleavage products. In addition, EcoRV fragments of both $8.35 \mathrm{~kb}$ and $6.75 \mathrm{~kb}$ were present in the same sample and both appeared to be amplified (Fig. 4, lane I), whereas in strain DU5863 only the $6.75 \mathrm{~kb}$ fragment was present (Fig. 4, lane J) and in strain DU5864 only the $8.35 \mathrm{~kb}$ fragment was present (Fig. 4, lane H). These data suggest that the coa gene had been amplified along with the $\Delta c o a:: \mathrm{Tc}^{\mathrm{r}}$ fragment. This could have occurred by two distinct unequal crossingover events as shown in Fig. 5.

Strain DU5881 was derived from strain DU5864 by a single selection step on $100 \mu \mathrm{g} \mathrm{Tc} \mathrm{ml}{ }^{-1}$. Southern blotting analysis of DNA from this strain showed $K p n I$ and EcoRV fragment patterns (Fig. 6, lanes G and K) similar to those of strain DU5857 (Fig. 1, lanes B and H), which was isolated directly after electroporation. However, strain DU5881 had an additional single-copy EcoRV fragment of $8.35 \mathrm{~kb}$, as the plasmid was previously shown to have integrated to the right of the coa locus in strain DU5864 (Fig. 2).

Strain DU5881 was then plated on higher concentrations of $\mathrm{Tc}$ to determine if further amplification events could be selected. A derivative was isolated (strain DU5884) which expressed resistance to $80 \mu \mathrm{g} \mathrm{Tc} \mathrm{ml} l^{-1}$. None of the colonies was capable of growing on 

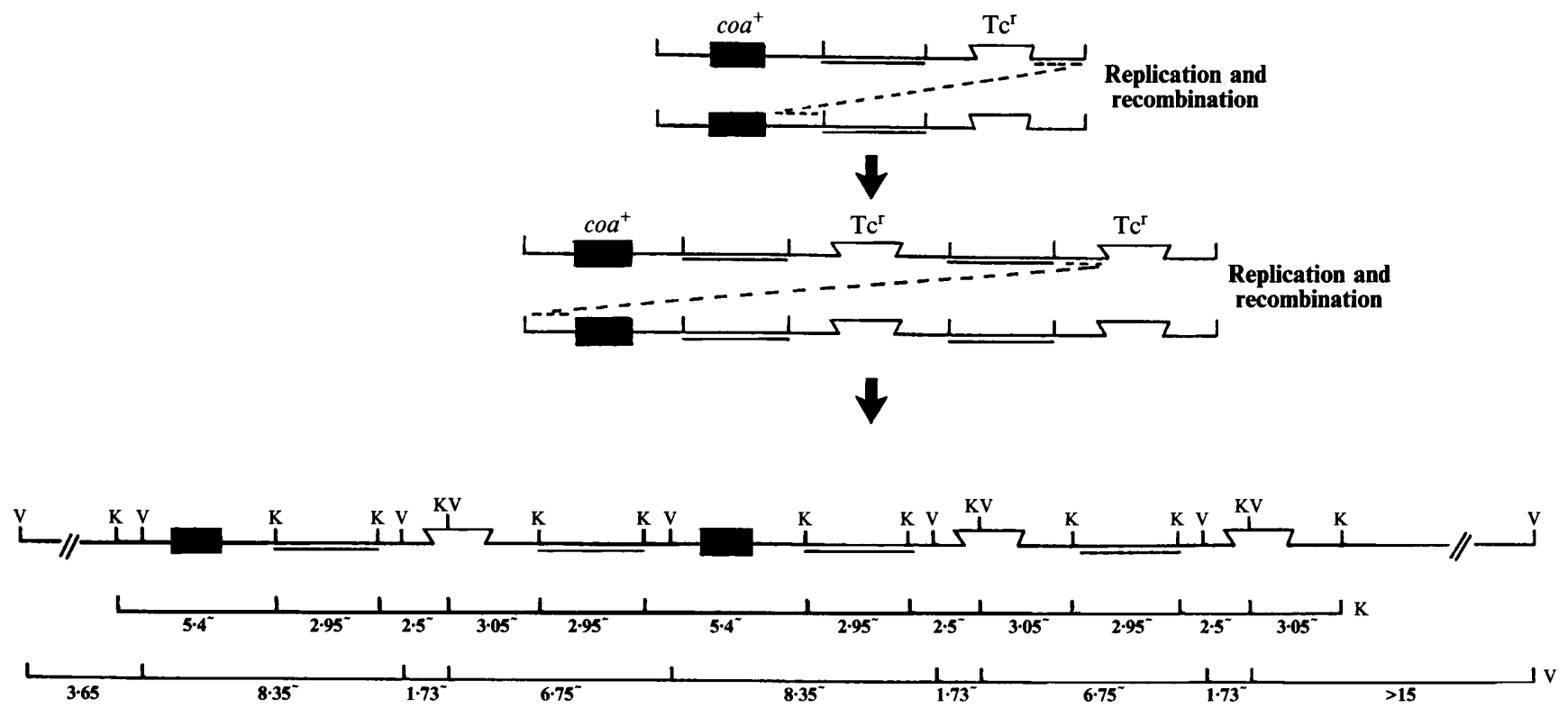

Fig. 5. Amplification of $\Delta c o a:: \mathrm{Tc}^{\mathrm{r}}$ and coa in strain DU5865. The top part of the diagram indicates the structure that would be generated if pCOA18 integrated into the chromosome by a single cross-over event to the right of the $\mathrm{Tc}^{\mathrm{r}}$ insertion (see Fig. 3). During chromosome replication, unequal crossing-over could occur on the right of the coa alleles to generate the structure in the middle of the diagram. A second unequal cross-over event on the other side of the coa alleles would generate the structure shown at the bottom of the diagram where both $\mathrm{coa}^{+}$and $\Delta c o a:: \mathrm{Tc}^{\mathrm{r}}$ are duplicated. This alternating structure could be further amplified during subsequent rounds of replication. V, EcoRV; K, KpnI; amplified fragments are marked .
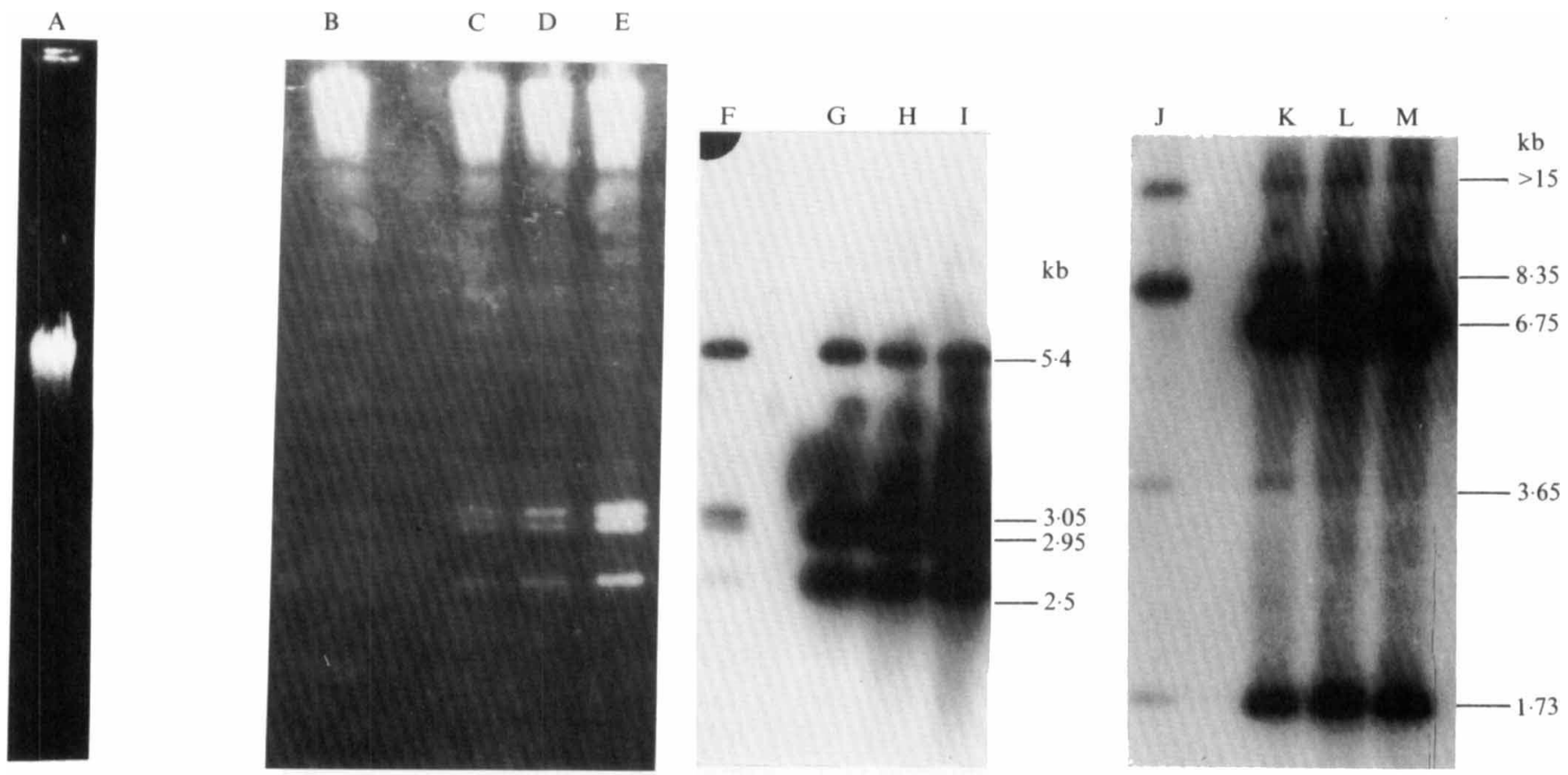

Fig. 6. Ethidium-bromide-stained gel and Southern blotting analysis of amplified strains. Chromosomal DNA from the single-copy integrant strain DU5864 was cleaved with KpnI (lanes B and F) and with EcoRV (lane J). DNA from the amplified strain DU5881 was cleaved with $K p n I$ (lanes $\mathrm{C}$ and G) and with $E c o$ RV (lane K) while DNA from the further amplified strain DU5884 was cut with $K p n I$ (lanes D and H) and with EcoRV (lane L). DNA from the amplified strain DU5885 was cleaved with KpnI (lanes E and I) and with EcoRV (lane M). Uncut DNA from strain DU5885 (lane A) was run as a control to show the absence of extrachromosomal multimeric plasmid DNA. Lanes A-E were stained with ethidium bromide while lanes F-M were probed with labelled pCOA14. The DNA loading in each lane was similar (about $10 \mu \mathrm{g}$ ). 
concentrations above $80 \mu \mathrm{g} \mathrm{Tc} \mathrm{ml} l^{-1}$ when tested by the $\mathrm{IC}_{50}$ method. Southern hybridization analysis revealed that this strain had a pattern of KpnI and EcoRV fragments (Fig. 6, lanes $\mathrm{H}$ and $\mathrm{L}$ ) similar to strain DU5881, except that the amplified bands seemed to be even more intense, suggesting that additional amplification had occured. Amplified KpnI fragments in stains DU5881 and DU5884 were clearly evident in ethidium-bromide-stained gels (Fig. 6, lanes C and D). Strain DU5885 was also isolated after two selection steps and expressed resistance to $125 \mu \mathrm{g} \mathrm{Tc} \mathrm{ml}^{-1}$. Amplified bands similar to strain DU5884 were observed in a stained gel (Fig. 6, lane E), and Southern blots with KpnI digests (Fig. 6, lane I) and EcoRV digests (Fig. 6, lane M). Extrachromosomal bands were not visible in a sample of uncut DNA from strain DU5885 (Fig. 6, lane A), indicating that the plasmid multimers are integrated in the chromosome. Also, there was no suggestion that excised monomers were present.

Autoradiograms of Southern blots with KpnI digests of the single-copy integrant strain DU5864 and the amplified-derivatives strains DU5881, DU5884 and DU5885 were scanned by a densitometer in order to estimate the number of tandem copies of pCOA18. Using the intensity of the single copy $5.4 \mathrm{~kb} \mathrm{KpnI} \mathrm{coa}$ fragment as a reference, the copy number of the amplified $2.5 \mathrm{~kb} K p n I$ fragment was estimated to be 9 (strain DU5881), 16 (strain DU5884) and 19 (strain DU5885). This correlated with resistance levels of $50 \mu \mathrm{g} \mathrm{Tc} \mathrm{ml} l^{-1}$, $80 \mu \mathrm{g} \mathrm{Tc} \mathrm{ml} l^{-1}$ and $125 \mu \mathrm{g} \mathrm{Tc} \mathrm{ml}^{-1}$ respectively.

\section{Discussion}

The underlying objective of this project was to investigate the possibility that allelic replacement mutants could be isolated in $S$. aureus with an integrating plasmid carrying an in-vitro-constructed mutation. Coagulase-deficient mutants were isolated and these have been extremely valuable in determining the relationship between coagulase and clumping factor and in analysing fibrinogen binding proteins of $S$. aureus (McDevitt et al., 1992). The characterization of some of the transformants isolated when pCOA18 was introduced into $S$. aureus strain RN4220 has led to the identification of a number of interesting structures. The majority of these transformants occurred as a result of a single recombination event between the mutated and wild-type alleles where the entire plasmid had integrated into the chromosome by a Campbell-type recombination event. Recombination was shown to have occured on either side of the wild-type gene. A double recombination event resulted in allele-replacement between the mutated and wild-type genes due to homologous sequences flanking the mutation. As predicted, this was a much rarer event.
Unexpectedly, the majority of Campbell insertions appeared to have multiple copies of pCOA18 in tandem arrays.

The 50 transformants chosen for analysis could be divided into three classes on the basis of phenotype and transduction analysis and by Southern hybridization using a coa probe and a probe for the $\mathrm{Tc}^{\mathrm{r}}$ insertion.

(1) Allele-replacement mutants were deficient in coagulase activity and expressed a low level of $\mathrm{Tc}^{\mathrm{r}}$ $\left(15 \mu \mathrm{g} \mathrm{m}^{-1}\right)$ from the single-copy $\mathrm{Tc}^{r}$ determinant. Variants expressing a higher level of $\mathrm{Tc}^{r}$ could not be selected. The $\mathrm{Tc}^{\mathrm{r}}$ and the $\mathrm{Coa}^{-}$phenotypes were $100 \%$ co-transducible, proving that the coa mutation was caused by the inserted Tc fragment. Southern blotting data was consistent with allelic replacement; no plasmid vector DNA was detected and single copies of fragments consistent with the $\Delta c o a:: \mathrm{Tc}^{\mathrm{r}}$ replacement were present in the chromosome.

(2) Single-copy Campbell integrants which were $\mathrm{Tc}^{\mathrm{r}}$ and $\mathrm{Coa}^{+}$. Transformants were isolated where integration had occurred on either side of the chromosomal coa locus. Single-copy integrants expressed the same low level of $\mathrm{Tc}^{\mathrm{r}}$ as the replacement mutant, but the population of cells in a colony or broth culture contained derivatives which expressed higher levels of $\mathrm{Tc}^{\mathrm{r}}$. These strains had amplified plasmid sequences as demonstrated by Southern hybridization. Transduction of a singlecopy Campbell integrant into a wild-type strain generated $\mathrm{Coa}^{-}$derivatives at a frequency of $19 \%$. These transductants had lost the plasmid but retained the $\Delta c o a:: \mathrm{Tc}^{\mathrm{r}}$ mutation and had the same properties as derivatives described in (1) above.

(3) Campbell integrants which carried multiple copies of pCOA18 in a tandem array were $\mathrm{Coa}^{+}$and were resistant to high levels of Tc (up to $125 \mu \mathrm{g} \mathrm{ml}^{-1}$ ). The frequency of transduction of $\mathrm{Tc}^{\mathrm{r}}$ to a $\mathrm{Coa}^{+}$recipient was 100 -fold higher than that of single-copy determinants. The majority of transductants were $\mathrm{Coa}^{+}$and expressed high levels of $\mathrm{Tc}^{\mathrm{r}}$, and thus probably had retained amplified copies of the plasmid sequences. An amplified pCOA18 integrant was isolated which was $\mathrm{Coa}^{-}$(strain DU5862) due to a deletion in the adjacent coa gene.

An explanation is lacking for the high incidence of multimerized pCOA18 among the $\mathrm{Tc}^{\mathrm{r}}$ transformants isolated in strain $\mathrm{RN} 4220$. The plasmid was predominantly monomeric when examined by gel electrophoresis (data not shown). However, dimers and multimers will always be present in any population of pUC- or pBR322-based plasmids (Summers \& Sherratt, 1984). It is feasible that multimeric plasmids are preferentially transformed by electroporation into $S$. aureus. The possibility that monomeric plasmids that were transformed into the same cell underwent recombination prior to integration is less likely. 
In Bacillus subtilis, the degree of amplification of a drug-resistance determinant that was forced to integrate into the chromosome is dependant on the concentration of the drug in the growth media (Young, 1984). However, in the case described here the transformants were selected on a low concentration of Tc $\left(2 \mu \mathrm{g} \mathrm{ml}^{-1}\right)$, which is well below the MIC for a single copy of the $\mathrm{Tc}^{\mathrm{r}}$ determinant. Indeed the single-copy integrants and replacement mutants did not grow any more slowly than the amplified derivatives when compared on agar containing $2 \mu \mathrm{g}$ $\mathrm{Tc} \mathrm{m} \mathrm{m}^{-1}$. However, as transformants were not induced for $\mathrm{Tc}^{\mathrm{r}}$ prior to plating, colonies containing multiple copies may have been better adapted for growth when initially plated on agar containing $2 \mu \mathrm{g} \mathrm{Tc} \mathrm{ml} l^{-1}$.

Tandem repeats of pCOA18 integrated in the chromosome could be selected by growing a single-copy integrant on high levels of Tc. This was presumably achieved by unequal recombination between two integrated plasmids as depicted in Fig. 3. This type of in situ gene amplification has been reported before in $S$. aureus (Matthew \& Stewart, 1988) and in Bacillus subtilis (Young, 1983; 1984). As in this case, when a demand was made for increased expression of a drug-resistance gene, amplified drug-resistance determinants were selected (Matthew \& Stewart, 1988; Young, 1984).

Densitometry was used to estimate the number of tandem copies of the amplified integrated plasmid in three strains. Strain DU5881, which was isolated after a single selection step, had about nine copies per chromosome. Strains DU5884 and DU5885, which had been isolated after two selection steps, had 16 and 19 copies per chromosome respectively. The tandemly amplified plasmid sequences appeared to be quite stable because after prolonged growth (100 generations) in drug-free broth, the single-cell resistance level had only dropped from $125 \mu \mathrm{g} \mathrm{Tc} \mathrm{ml} l^{-1}$ to $75 \mu \mathrm{g} \mathrm{Tc} \mathrm{ml}^{-1}$. Reiterated sequences are also stable in the Bacillus subtilis chromosome (Young \& Ehrlich, 1989).

Transducing phage propagated on strains that contained amplified copies of pCOA18 in the chromosome transferred the $\mathrm{Tc}^{\mathrm{r}}$ marker at a frequency about 100 -fold higher than for single-copy determinants. Many of the transductants formed very small colonies which either failed to grow when replated or formed a mixture of small and large colonies. We suspect that abortive transduction is occuring with linear fragments or with circular molecules comprising tandem arrays of pCOA 18 being introduced into the recipient by transduction and cells growing initially due to the presence of multiple copies of the $\mathrm{Tc}^{\mathrm{r}}$ determinant.

Integrating plasmids introduced by electroporation offer an alternative approach to temperature-sensitive and incompatible plasmids for genetic manipulation in $S$. aureus. If the transformation frequency is sufficiently high, allelic-replacement may be detected directly after plating transformants. Alternatively, transduction of a single-copy integrant allows the allele-replacement recombination event to be readily selected. The disadvantage of the integrating plasmid approach is that it is confined to the recipient strain RN4220. Mutagenesis can be performed in many other strains, even those in different phage groups, only if replicative plasmiddelivery systems are employed.

We thank Dr J. Hassan of the Childrens' Research Centre, Our Lady's Hospital for Sick Children Crumlin, Dublin, for her assistance in the use of the densitometer.

\section{References}

Anderson, J. C., Adlam, C. \& Knights, J. M. (1982). The effect of staphylocoagulase in the mammary gland of the mouse. British Journal of Experimental Pathology 63, 336-340.

ANDERSON, R P. \& Roth, J. R. (1977). Tandem genetic duplication in phage and bacteria. Annual Review of Genetics 31, 473-505.

AsHeSHOV, E. H. (1966). Loss of antibiotic resistance in Staphylococcus aureus resulting from growth at high temperatures. Journal of General Microbiology 42, 403-410.

Ausubel, F. M., Brent, R., Kingston, R. E., Moore, D. D., Smith, J. A., Seidman, J. G. \& Struhl, K. (1987). Current Protocols in Molecular Biology. New York: John Wiley.

Duthie, E. S. \& Lorenz, L. L. (1952). Staphylococcal coagulase: mode of action and antigenicity. Journal of General Microbiology 6, 95-107.

Finlay, B. B. (1992). Genetic approaches to understanding pathogenesis of complex bacterial pathogens. Symposia of the Society for General Microbiology 49, 33-45.

Foster, T. J. (1992). The use of mutants for defining the role of virulence factors in vivo. Symposia of the Society for General Microbiology 49, 173-192.

Foster, T. J. \& McDevitT, D. (1992). Genetic analysis of Staphylococcus aureus virulence. In Molecular Pathogenesis of Surgical Infections. Edited by T. Wadstrom, I. Holder \& J. Kronvall. London: Springer.

Jones, J. M., Yost, S. C. \& PATtee, P. A. (1987). Transfer of the conjugal tetracycline resistance transposon Tn916 from Streptococcus faecalis to Staphylococcus aureus and identification of some insertion sites in the staphylococcal chromosome. Journal of Bacteriology 169, 2121-2131.

Kreiswirth, B. N., Lofdahl, M. S., Betley, M. J., O'Reilly, M., Schlievert, P. M., Bergdoll, M. S. \& Novick, R. P. (1983). The toxic shock syndrome exotoxin structural gene is not detectably transmitted by a prophage. Nature, London 305, 709-712.

McDevitT, D., VaudauX, P. \& Foster, T. J. (1992). Genetic evidence that bound coagulase of Staphylococcus aureus is not clumping factor. Infection and Immunity 60, 1514-1523.

MatThew, P. R. \& Stewart, P. R. (1988). Amplification of a section of chromosomal DNA in methicillin-resistant Staphylococcus aureus following growth in high concentrations of methicillin. Journal of General Microbiology 134, 1455-1464.

MeKalanos, J. J. (1983). Duplication and amplification of the toxin genes from Vibrio cholerae. Cell 35, 253-263.

Miller, J. H. (1972). Experiments in Molecular Genetics. Cold Spring Harbor, NY: Cold Spring Harbor Laboratory.

O'Reilly, M., De Azavedo, J. C. S., Kennedy, S. \& Foster, T. J. (1986). Inactivation of the $\alpha$-haemolysin gene of Staphylococcus aureus $8325-4$ by site-directed mutagenesis and studies on expression of its haemolysins. Microbial Pathogenesis 1, 125-138.

Oskouian, B. \& StewaRT, G. C. (1990). Repression and catabolite repression of the lactose operon of Staphylococcus aureus. Journal of Bacteriology 172, 3804-3812. 
Patel, A. H., Nowlan, P., Weavers, E. D. \& Foster, T. J. (1987). Virulence of protein A-deficient mutants of Staphylococcus aureus isolated by allele-replacement. Infection and Immunity 55, 3103-3110.

Pattee, P. A. (1981). Distribution of Tn551 insertion sites responsible for auxotrophy on the Staphylococcus aureus chromosome. Journal of Bacteriology 145, 479-488.

Phonimdaeng, P., O'Reilly, M., O'Toole, P. W. \& Foster, T. J. (1988). Molecular cloning and expression of the coagulase gene of Staphylococcus aureus 8325-4. Journal of General Microbiology 134, 75-83.

Phonimdaeng, P., O'Reilly, M., Nowlan, P., Bramley, A. J. \& FOSTER, T .J. (1990). The coagulase of Staphylococcus aureus 8325-4. Sequence analysis and virulence of site-specific coagulase-deficient mutants. Molecular Microbiology 4, 393-404.

Rigby, P. W. J., Diekmann, M., Rhodes, C. \& Berg, P. (1977). Labelling deoxyribonucleic acid to high specific activity in vitro by nick-translation with DNA polymerase. Journal of Molecular Biology 113, 237-251.

Sambrook, J., Fritsch E. F. \& Maniatis, T. (1989). Molecular Cloning: A Laboratory Manual, 2nd edn. Cold Spring Harbor NY: Cold Spring Harbor Laboratory.

Short, J. M., Fernandez, J. M., Sorge, J. A. \& Huse, W. D. (1988). AZAP; a bacteriophage expression vector with in vivo expression properties. Nucleic Acids Research 16, 7583-7587.
Sloane, R., De Azevado, J. C. S., Arbuthnott, J. P., Hartigan, P. J., KreisWirth, B., Novick, R. P. \& Foster, T. J. (1991). A toxic shock syndrome toxin mutant of Staphylococcus aureus isolated by allelic-replacement lacks virulence in a rabbit uterine model. FEMS Microbiology Letters 78, 239-244.

SOUTHERN, E. M. (1975). Detection of specific sequences amoung DNA fragments seperated by gel electrophoresis. Journal of Molecular Biology 98, 503-517.

Summers, D. K. \& SherRatT, D. T. (1984). Multimerization of high copy number plasmids causes instability: ColE1 encodes a determinant essential for plasmid monomerization and stability. Cell 36, 1097-1103.

Wilson, C. R., Skinner, S. E. \& ShaW, W. V. (1981). Analysis of two chloramphenicol resistance plasmids from Staphylococcus aureus: insertional inactivation of $\mathrm{Cm}$ resistance, mapping of restriction sites and construction of cloning vehicles. Plasmid 5, 245-258.

YounG, M. (1983). The mechanisms of insertion of a segment of heterologous DNA into the chromosome of Bacillus subtilis. Journal of General Microbiology 129, 1497-1512.

YounG, M. (1984). Gene amplification in Bacillus subtilis. Journal of General Microbiology 130, 1613-1621.

Young, M. \& EHRLICH, S. D. (1988). Stabilily of reiterated sequences in the Bacillus subtilis chromosome. Journal of Bacteriology 171, 2653-2656. 